Mikhail Kanarsky ${ }^{1}$, Julia Nekrasova ${ }^{1,2}$, Dmitry Yankevich¹, Ekaterina Bondar', Margarita Radutnaya ${ }^{1}$, Igor Znamensky ${ }^{1}$, Anton Kudryavtsev', Ilya Borisov' ${ }^{1}$, Pranil Pradhan', Victoria Endler', Kirill Cherkashin', Maria Miroshnichenko ${ }^{1}$

${ }^{1}$ Federal State Budget Scientific Institution — Federal Research and Clinical Center of Intensive Care Medicine and Rehabilitology, Moscow, Russia

${ }^{2}$ Federal State Budgetary Educational Institution of Higher Education - Moscow Aviation Institute (National Research University), Moscow, Russia

\title{
Anoxic brain injury due to global ischemia: analysis of three clinical cases
}

\begin{abstract}
The article analyses three clinical cases of patients in a permanent vegetative state due to cardiac arrest and prolonged cardiopulmonary resuscitation. All patients were admitted to Federal State Budget Scientific Institution - Federal Research and Clinical Center of Intensive Care Medicine and Rehabilitology, Moscow, Russia. For diagnosing and prognosis for the progression of the disease a detailed examination was held, including electroencephalography, polysomnography, positron emission computed tomography, singlephoton emission computed tomography, functional perfusion computed tomography, electroneuromyography, evoked potentials studies, laboratory studies, and other available tests. Instrumental diagnostics methods confirm the principal component that determines the level of consciousness in this type of damage - diffuse damage to the cerebral cortex. To conclude realization of the rehabilitation potential of such patients is impossible without the control of nutritional support. Amino acid profile is one of the markers and ways to control metabolic function.
\end{abstract}

Palliat Med Pract 2021; 15, 1: 84-92

Key words: disorders of consciousness, global ischemia, amino acid profile, rehabilitation potential, melatonin

\section{Introduction}

Cardiac arrest is the cessation of electrical activity and, as a result, the contractile ability of the heart, which leads to a complete siege of the delivery of oxygen and glucose to tissues [1]. After about 20 seconds of oxygen depletion, clinically it is manifested by loss of consciousness, and after 5 minutes, there is depletion of glucose and oxygen reserves in the very sensitive to them nervous tissue. Suspension of the synthesis of adenosine triphosphate (ATP) makes it impossible to perform the work of the ATP-dependent $\mathrm{Na} / \mathrm{K}$-ion pump, which in turn leads to dysfunction of the cell membrane, redistribution of $\mathrm{Na}$ and the entry of Ca into the cell [2]. An increase in the membrane permeability for $\mathrm{Ca}$ causes the activation of calmodulin-dependent protein kinases, lipases, and endonucleases, which in turn leads to damage to the membrane

\section{Address for correspondence:}

Julia Nekrasova

Federal State Budget Scientific Institution — Federal Research and Clinical Center of Intensive Care Medicine and Rehabilitology, Moscow, Russia

e-mail: nekrasova84@yandex.ru

Palliative Medicine in Practice $2021 ; 15,1,84-92$

Copyright @ Via Medica, ISSN 2545-0425

DOI: 10.5603/PMPI.2021.0001

This article is available in open access under Creative Common Attribution-Non-Commercial-No Derivatives 4.0 International (CC BY-NC-ND 4.0) license, allowing to download articles and share them with others as long as they credit the authors and the publisher, but without permission to change them in any way or use them commercially. 
and cellular organelles, and the release of glutamate, mediated by the penetration of $\mathrm{Ca}$ into the cell causing the phenomenon of excitotoxicity. A significant role in both ischemia and reperfusion is played by an increase in the production of free radicals, leading to a series of pathological biochemical processes. Ultimately, this leads to cell death, by the mechanisms of necrosis, apoptosis, and pyroptosis $[3,4]$.

The projection neurons of the cerebral cortex, the Purkinje cells of the cerebellum, and the cornu ammonis (CA-1) layer of the hippocampus are areas particularly prone to ischemia. On the contrary, the brain stem, thalamus, and hypothalamus are more tolerant to ischemia [5]. In multiple ways, it is this difference in sensitivity to ischemia that causes chronic impairment of consciousness after cardiac arrest and subsequent cardiopulmonary resuscitation (CPR). With a comparatively intact function of the brain stem and hypothalamic structures, there is significant damage to the associative, commissural, thalamocortical fibres, which are the cause of the vegetative state [6].

Advances in resuscitation resulted in an increased survival rate of patients due to the sudden cardiac arrests [3]. In Russia, cardiac arrest kills approximately 250,000 people every year. About $10 \%$ survive in out-of-hospital settings whereas, on the opposite in clinics and hospitals, this figure reaches higher about $22 \%$. Approximately one-third of patients who have survived circulatory arrest retain persistent neurological deficits [1]. Reperfusion injury occurs at the onset of CPR, causing oxidative stress and the formation of free radicals and reactive oxygen species [3]. They are highly destructive and react with many macromolecules, including deoxyribonucleic acid (DNA), proteins, and lipids. Besides that, global reperfusion leads to the activation of leukocytes, inducing an inflammatory stress response, disrupting the blood-brain barrier, and promoting further damage due to fluid leakage into the intracellular space, which leads to cerebral oedema [3]. CPR partially reverses ischemia but is unable to maintain cerebral perfusion pressure efficiently, so the perfusion pressure remains low until the restoration of the natural blood flow, after which further reperfusion injury occurs [7].

Taking into account the substantial damage that occurs as a result of CPR, the decision on the time of its termination CPR in patients without natural circulations is contradictory and complex. The European and American Resuscitation Councils suggest discontinuing CPR after 20 minutes of asystole, but this is generally not done in practice. It is worth noting that some people undergo more prolonged CPR with minimal neurological consequences, which indicates that every person has an individual tolerance to hypoxia, so it is not acceptable to stop resuscitation just due to poor prognosis of neurological deficit [7].

The formation of a vegetative state (VS) due to global anoxia is an adverse prognostic phenomenon [8]. The vegetative state is considered permanent 3 months after non-traumatic brain injury. Permanent VS means the impossibility of further restoration of consciousness $[9,10]$. This paper analyses three clinical cases of patients in permanent vegetative state due to cardiac arrest and prolonged CPR who were admitted for rehabilitation to Federal State Budget Scientific Institution - Federal Research and Clinical Centre of Intensive Care Medicine and Rehabilitology, Moscow, Russia.

\section{Case 1}

\section{Medical history}

On 04.10.2019, during transcatheter aortic valve implantation for stenosis of the aortic orifice, cardiac arrest occurred in a 75 years old man. Resuscitation took 33 minutes. From 04.10.2019 to 14.10 .2019 , the patient was in a coma. From 15.10.2019, he went into a vegetative state.

\section{Neurological status on admission}

Vegetative state. Coma recovery scale - revised (CRS-R): $1+1+1+0+0+1=4$ points. Stem reflexes are preserved. Muscle tone is reduced in all limbs (26.11.2019).

\section{Instrumental diagnostic methods}

Computed tomography (CT) scan of the brain and perfusion computed tomography (CTP) (26.11.2019). In a CT scan, the patient presented a noticeable decrease in the density of the grey matter of the brain, the changes were more pronounced around the lateral ventricles. During the CTP scan, there was a decrease in the volume and velocity of blood flow in the areas of leukoaraiosis, around the temporal horns, and there were areas where all perfusion parameters were decreased (Fig. 1A).

\section{The study of the evoked potentials of the brain}

According to the evoked potentials studies against the background of maintaining normal conduction from the peripheral level (27.11.2019), there was difficulty in conduction at the level of intra stem structures, as well as a decrease in the amplitude of the cortical response on both sides with an increase in the time of central conduction (left), which also indicates difficulty in conduction of afferent signals in the cerebral cortex (Fig. 2A). 


\section{Electroneuromyography}

The patient underwent stimulation myography of the long nerves of the upper extremities (27.11.2019). There was a pronounced decrement in the motor response amplitude from all nerves with a decrease in the rate of excitation propagation along the left ulnar and median nerves. The findings indicated an axonal-demyelinating lesion (Fig. 3A).

\section{Electroencephalography}

The routine study was conducted on 28.11.2019 with the Nicolet w10-20HB device. The electroencephalography (EEG) shows diffuse slow-wave activity mainly in the delta range with a frequency of $0.5 \mathrm{~Hz}$ and an amplitude of up to $60 \mathrm{mV}$. There was no reactivity of the rhythm to external stimuli (Fig. 4A).

\section{Polysomnographic study}

The study was carried out on 10.03.2020 with the SOMNOscreen polysomnographic (PSG) device and specialized software developed in Federal Research and Clinical Center of Intensive Care Medicine and Rehabilitology for analysing sleep patterns. According to the Rechtschaffen and Kales method [11], brain activity during an overnight period is classified as Stage I of slow-wave sleep (drowsing state) with rare emergence to Stages III-IV. Stage II of slow-wave sleep, sleep spindles, and K-complexes are absent. No sign of paradoxical sleep is found. The electrooculogram exhibited rapid eye movements, which, however, cannot be classified as rapid eyes movements (REM) sleep due to the absence of muscle atony during these periods. No rhythmic change in sleep stages were found in polysomnographic tracks. This gives ground to conclude about the deep disorders of sleep-wake cycle and absence of normal sleep patterns (Fig. 5A).

\section{Positron emission computed tomography and single-photon emission computed tomography}

In the single-photon emission computed tomography (SPECT) and positron emission computed tomography (PET-CT) with 18-fluorodeoxyglucose (18-FDG) brain scan of the patient (26.02.2020), there is a sharp reduction in the accumulation of radiopharmaceutical (RP) in the cerebral cortex, to a lesser extent in the cerebellum, brainstem, and basal nuclei. These changes do correspond with diffuse anoxic brain damage. PET-CT data determines a decrease in the accumulation of RP (18-FDG). When quantitatively assessing the average level of RP accumulation, a symmetric reduced accumulation of FDG in the frontal, parietal, temporal and occipital lobes is determined, up to a maximum of SUVmean $=1.5$. In addition, the symmetrical accumulation of RP at the level of the basal nuclei is determined up to SUVmean $=1.9$. SUVmax in gray matter $=0.9$; SUVmax in white matter $=0.8$. The ratio of maximum accumulation in gray and white matter is 1.14 ( $\mathrm{N}$ more than $\mathrm{M}=2.38 \pm 0.33)$. In the white matter of the brain, zones of a pronounced decrease in X-ray density are diffusely determined, corresponding to areas of decrease in the accumulation of RP. Thus, diffuse brain damage is determined (Fig. 6A).

\section{Laboratory diagnostics}

The results of laboratory tests of the patient are presented in Table 1.

\section{Neurological status on follow up}

Vegetative state. CRS-R: $1+1+1+0+0+2=5$ points. Increment in muscle tone (09.04.2020).

\section{Case 2}

\section{Medical history}

On August 10, 2019, the 45 years old patient complained of chest pain, 4 hours after the onset of the pain, an ambulance was called. During the examination, there was ventricular fibrillation with a transition to asystole. Resuscitation took 20 minutes. The patient got admitted to the hospital, where he got the diagnosis of coronary heart disease: acute anterior lateral myocardial infarction with S-T segment elevation. Recanalization, balloon vasodilation, and stenting of the anterior descending artery were performed. On August 21, the patient emerged from a coma into a vegetative state.

\section{Neurological status on admission}

Vegetative state. CRS-R: $1+0+2+0+0+2=5$ points. Reacted to a painful stimulus with minimal flexion of the upper limbs. Lower jaw movements - trismus. Brainstem reflexes are preserved. Muscle tone is reduced in the lower extremities, increased in spasticity in the upper extremities (according to the modified Ashworth spasticity scale up to 2$)(11.10 .2019)$.

\section{Instrumental diagnostic methods}

Computed tomography of the brain and perfusion computed tomography

Computed tomography scan (14.10.2019), a noticeable decrease in the density of grey matter around the ventricles was noted, changes were more pronounced at the level of the posterior and temporal horns of the lateral ventricles, as well as an area of reduced density was also revealed in the region of the basal nuclei on the left. According to CTP scan, there was 
Table 1. The results of laboratory test of the patient

\begin{tabular}{|c|c|c|c|c|}
\hline Diagnostic tests & Results & Units & Normal range & Comments \\
\hline Cortisol at 2 a.m. & 17 & $\mu \mathrm{g} / \mathrm{dl}$ & $2.5-12.5$ & High \\
\hline Serotonin & 348.09 & $\mathrm{ng} / \mathrm{ml}$ & $70-270$ & Very high \\
\hline Melatonin at 2:00 a.m. & 1.3 & $\mathrm{pg} / \mathrm{ml}$ & $\begin{array}{l}\text { Morning: } \\
\text { 15.0-30.0 } \\
\text { Afternoon: } \\
\text { < } 4.9 \\
\text { Evening (from } 22 \text { to } 24 \text { ): } \\
8.0-40.0 \\
\text { Night: } \\
52.3-149.4\end{array}$ & Very low \\
\hline Alanine (blood) & 198.00 & $\mu \mathrm{mol} / \mathrm{l}$ & 239-345 & Low \\
\hline Arganine (blood) & 36.00 & $\mu \mathrm{mol} / \mathrm{l}$ & $53-71$ & Low \\
\hline Aspartic acid (blood) & 4.53 & $\mu \mathrm{mol} / \mathrm{l}$ & $0.9-7.4$ & \\
\hline Valine (blood) & 74.7 & $\mu \mathrm{mol} / \mathrm{l}$ & 80-199 & Low \\
\hline Glycine (blood) & 409.00 & $\mu \mathrm{mol} / \mathrm{l}$ & $178-513$ & \\
\hline Glutamic acid (blood) & 31.40 & $\mu \mathrm{mol} / \mathrm{l}$ & $18.1-155.9$ & \\
\hline Leucine + Isoleucine (blood) & 61.30 & $\mu \mathrm{mol} / \mathrm{l}$ & $70-145$ & Very low \\
\hline Lysine (blood) & 121.00 & $\mu \mathrm{mol} / \mathrm{l}$ & $94-278$ & \\
\hline Methionine (blood) & 18.50 & $\mu \mathrm{mol} / \mathrm{l}$ & $15-37$ & \\
\hline Ornithine (blood) & 44.60 & $\mu \mathrm{mol} / \mathrm{l}$ & $39-61$ & \\
\hline Proline (blood) & 333.00 & $\mu \mathrm{mol} / \mathrm{l}$ & $110-417$ & \\
\hline Serine (blood) & 62.70 & $\mu \mathrm{mol} / \mathrm{l}$ & $48.7-145.2$ & \\
\hline Tyrosine (blood) & 78.30 & $\mu \mathrm{mol} / \mathrm{l}$ & $33-146$ & \\
\hline Tryptophan (blood) & 21.50 & $\mu \mathrm{mol} / \mathrm{l}$ & 23.5-93 & Low \\
\hline Phenylalanine (blood) & 63.7 & $\mu \mathrm{mol} / \mathrm{l}$ & $45-93$ & \\
\hline Citrulline (blood) & 12.00 & $\mu \mathrm{mol} / \mathrm{l}$ & $10-43$ & \\
\hline
\end{tabular}

a decrease in the volume and velocity of blood flow around the ventricles and the occipital lobes, including at the level of the white matter of the occipital lobes (Fig. 1B).

\section{Functional magnetic resonance imaging}

Within the framework of the study, the rest state networks were mapped, which characterized the activity of the brain that did not get involved in performing any special task (in the medical literature also known as resting state) [12-14] or the state of rest/relaxed wakefulness. Due to the inaccessibility of the patient for contact, instructions were not given. In the course of the study, the visual network in its classical form was not detected, but activation of the visual cortex took place. The network of executive functions, the network of salience, and the speech network which are typical of conscious patients were not distinguished. The auditory and sensorimotor networks were not distinguished as well.

When analysing the default networking, it was a complete absence of the posterior (parietal and median) components of activation, a decrease in the frequency, and general disorganization of oscillations of the anterior network nodes in the patient compared to the norm. In the resting visual network, the patient has a significant decrease in the amplitude of activation, as well as an irregular low-frequency and low-amplitude nature of the rhythm in comparison with the norm (29.10.2019) (Fig. 7A).

\section{Twelve-hour electroencephalographic monitoring}

The activity on the EEG (17.10.2019) is close to the isoline (the signal amplitude does not exceed $5 \mu \mathrm{V}$ ). The background curve is dominated by low-amplitude slow-wave activity, mainly in the delta range with a frequency of $0.5-1.5 \mathrm{~Hz}$. (Fig. 4B). No changes were observed in the background EEG activity over time.

\section{Polysomnographic study}

On the hypnogram from 14.01.2020 (Fig. 5B), there is a disorganized change in polygraphic indicators. The dominant slow-wave activity of the brain, 
classified as Stages III-IV of slow-wave sleep, is replaced by a polysomnographic picture corresponding to stage I or wake, which is most likely due to the increased muscle activity during these periods and the appearance of muscle artefacts in the EEG.

\section{Evoked potentials of the brain}

On 17.10.2019 the patient underwent a study of somatosensory evoked potentials (SSEP) by stimulation of the median nerves on both sides. According to the SSEP study, the response parameters from the peripheral level remain within the normal range $(D>S)$. The conduction was slightly hindered at the level of the brainstem structures on the left (along the upper limit of the norm). The amplitude of the cortical response is reduced on both sides (more on the left) with an increase in the time of central conduction. There are no cortical responses. The data obtained indicate the difficulty of afferentation in the cerebral cortex.

On 27.12.2019, the patient underwent a study of acoustic stem evoked potentials (ASEP) and visual evoked potentials (VEP) (please see Supplementary files, Figure 2B). According to the results of the analysis of ASEP, difficulty in conducting at the level of the intra-brainstem auditory structures on the right was noted: an increase in the latency of peaks I, V, a decrease in the amplitude of peak $\mathrm{V}$.

According to the results of the analysis of the VEP with LED flash, there is a difficulty in conducting at the chiasmal level on both sides (decrease in the P100 amplitude). The amplitude of the cortical response is reduced on both sides (more on the left) with the preservation of the central conduction time.

\section{Single-photon emission computed tomography and positron emission computed tomography}

A visual assessment of SPECT and PET-CT of the brain of this patient of tomographic sections reveals a significant decrease in the accumulation of RP, mainly in the right hemisphere of the brain, parietal lobes on both sides, due to a pronounced decrease in cerebral blood flow in the brain as a result of anoxic damage (07.02.2020) (Fig. 6B).

A visual assessment of PET-CT data of the brain determines a decrease in the accumulation of RP. The average level of RP accumulation, symmetric accumulation of 18-FDG in the frontal, parietal, temporal and occipital lobes is determined to a maximum of SUVmean $=3.2$. Additionally, the symmetric accumulation of RP at the level of the basal nuclei is determined up to standardized uptake value (SUV) mean $=5.8$. SUV max in gray matter $=4.7$; SUV max in white matter $=3.4$. In the occipital lobes, zones of a decrease in the X-ray density of white matter with a concomitant decrease in the accumulation of 18-FDG are locally determined. The X-ray density of the white matter of the brain is reduced, mainly in the periventricular regions. Thus, diffuse brain damage is determined.

\section{Laboratory diagnostics}

The results of laboratory tests of the patient are presented in Table 2.

\section{Neurological status at the time of discharge}

Vegetative state. CRS-R: $1+1+2+0+0+2=6$ points. There is an increase in muscle tone in the lower extremities bilaterally in the proximal and distal regions up to 2 points on the modified Ashworth spasticity scale. In the upper extremities bilaterally in the proximal and distal sections up to 3 points (10.04.2020).

\section{Case 3}

\section{Medical history}

From the medical records, a 36 years old patient was taken to the hospital from the accident scene (motorcyclist) on September 6, 2019. On 12.09.2019, the cardiac arrest took place during splenectomy. The duration of CPR is not known. On 20.09.2019, retreat from a coma into a vegetative state.

\section{Neurological status on admission}

Vegetative state. CRS-R: $1+0+1+0+0+2=4$ points. Reaction to pain stimulus: minimal arm flexion. Stem reflexes are preserved. Reduced muscle tone in the limbs. Increased muscle tone in the oramandibular muscles (25.10.2019).

\section{Instrumental diagnostic methods}

Computed tomography scan of the brain and computed tomography perfusion

In a CT scan, the patient had symmetric zones of decreased density in the parietal and occipital lobes. During CTP, there was a significant decrease in blood flow velocity as well as in blood volume in the occipital lobes and temporal lobes (Fig. 1C).

\section{Electroneuromyography}

The patient underwent stimulation myography of the long nerves of the upper extremities. The amplitude of the motor response from both median and ulnar nerves is reduced at all points of stimulation. The speed of propagation of excitation along all the nerves that were studied was kept within the normal range. The data obtained are characteristic of lesions at the axonal level (19.11.2019) (Fig. 1B). 
Table 2. The results of laboratory test of the patient

\begin{tabular}{|c|c|c|c|c|}
\hline Diagnostic tests & Results & Units & Normal range & Comments \\
\hline Cortisol at 2 a.m. & 14 & $\mu \mathrm{g} / \mathrm{dl}$ & $2.5-12.5$ & High \\
\hline Serotonin & 175.43 & $\mathrm{ng} / \mathrm{ml}$ & $70-270$ & \\
\hline Melatonin at 2:00 a.m. & 7,2 & $\mathrm{pg} / \mathrm{ml}$ & $\begin{array}{l}\text { Morning: } \\
\text { 15.0-30.0 } \\
\text { Afternoon: } \\
\text { < } 4.9 \\
\text { Evening (from } 22 \text { to } 24 \text { ): } \\
8.0-40.0 \\
\text { Night: } \\
52.3-149.4\end{array}$ & Low \\
\hline Alanine (blood) & 295.00 & $\mu \mathrm{mol} / \mathrm{l}$ & 239-345 & \\
\hline Arganine (blood) & 53.00 & $\mu \mathrm{mol} / \mathrm{l}$ & $53-71$ & \\
\hline Aspartic acid (blood) & 2.52 & $\mu \mathrm{mol} / \mathrm{l}$ & $0.9-7.4$ & \\
\hline Valine (blood) & 89.5 & $\mu \mathrm{mol} / \mathrm{l}$ & $80-199$ & \\
\hline Glycine (blood) & 218.00 & $\mu \mathrm{mol} / \mathrm{l}$ & $178-513$ & \\
\hline Glutamic acid (blood) & 30.10 & $\mu \mathrm{mol} / \mathrm{l}$ & $18.1-155.9$ & \\
\hline Leucine + Isoleucine (blood) & 71.60 & $\mu \mathrm{mol} / \mathrm{l}$ & $70-145$ & \\
\hline Lysine (blood) & 75.50 & $\mu \mathrm{mol} / \mathrm{l}$ & $94-278$ & Low \\
\hline Methionine (blood) & 16.00 & $\mu \mathrm{mol} / \mathrm{l}$ & $15-37$ & \\
\hline Ornithine (blood) & 53.50 & $\mu \mathrm{mol} / \mathrm{l}$ & $39-61$ & \\
\hline Proline (blood) & 292.00 & $\mu \mathrm{mol} / \mathrm{l}$ & $110-417$ & \\
\hline Serine (blood) & 84.20 & $\mu \mathrm{mol} / \mathrm{l}$ & $48.7-145.2$ & \\
\hline Tyrosine (blood) & 86.00 & $\mu \mathrm{mol} / \mathrm{l}$ & $33-146$ & \\
\hline Tryptophan (blood) & 80.40 & $\mu \mathrm{mol} / /$ & $23.5-93$ & \\
\hline Phenylalanine (blood) & 66.7 & $\mu \mathrm{mol} / \mathrm{l}$ & $45-93$ & \\
\hline Citrulline (blood) & 17.20 & $\mu \mathrm{mol} / \mathrm{l}$ & $10-43$ & \\
\hline
\end{tabular}

\section{Evoked potentials}

The multimodal evoked potentials study — somatosensory evoked potentials (SSEP), auditory evoked potentials (ASEP), and visual evoked potentials (VEP) was performed in the patient on 04.02.2020 and 05.02.2020. According to the study of SSEP, there are signs of preservation of the response parameters from the peripheral level, but found to be difficult in conduction at the level of intrastem structures (an increase in the latency of the N13 peak) and a decrease in the amplitude of the cortical response on both sides (more on the left) with an increase in the time of central conduction (left), which indicates a difficulty in afferentation in the cerebral cortex. The study of ASEP revealed a slowing of conduction in the distal part of the auditory nerve on the right (peak I), in the lower tubercles of the quadruple (peak V). Analysis of the VEP on the light-emitting diode (LED) flash shows the difficulty of conduction at the level of intrastem auditory structures (decrease in the amplitude of the peak P100) on both sides while maintaining normal conduction at the level of the chiasm (Fig. 2C).

\section{Electroencephalography}

On the EEG from 01.11.2019, there is a slow electrical activity, where electrical activity is dominated by delta-range waves (Fig. 4C). There were no significant changes in the dynamics during the EEG from 04.02.2020 and 11.03.2020.

\section{Polysomnographic study}

The hypnogram (Fig. 5C) shows a change from an intermediate rapid low-wave amplitude to a slow-wave activity corresponding to the II-IV stages of sleep in a healthy person. However, the above described change of sleep patterns is not cyclical; the presence of intermediate fast-wave activity at the beginning of the sleep period may be explained by casting of muscle artefacts in the EEG. Thus, it is not possible to draw a clear conclusion about the presence or absence of sleep during the period un- 
Table 3. The results of laboratory tests of the patient

\begin{tabular}{|c|c|c|c|c|}
\hline Diagnostic tests & Results & Units & Normal range & Comments \\
\hline Cortisol at 2 a.m. & 13,5 & $\mu \mathrm{g} / \mathrm{dl}$ & $2.5-12.5$ & High \\
\hline Serotonin & 301.67 & $\mathrm{ng} / \mathrm{ml}$ & $70-270$ & Very high \\
\hline Melatonin at 2:00 a.m. & 37,2 & $\mathrm{pg} / \mathrm{ml}$ & $\begin{array}{l}\text { Morning: } \\
\text { 15.0-30.0 } \\
\text { Afternoon: } \\
\text { < } 4.9 \\
\text { Evening (from } 22 \text { to } 24 \text { ): } \\
8.0-40.0 \\
\text { Night: } \\
52.3-149.4\end{array}$ & \\
\hline Alanine (blood) & 167.00 & $\mu \mathrm{mol} / \mathrm{l}$ & 239-345 & Low \\
\hline Arganine (blood) & 34.20 & $\mu \mathrm{mol} / \mathrm{l}$ & $53-71$ & Low \\
\hline Aspartic acid (blood) & 2.75 & $\mu \mathrm{mol} / \mathrm{l}$ & $0.9-7.4$ & \\
\hline Valine (blood) & 75.0 & $\mu \mathrm{mol} / \mathrm{l}$ & 80-199 & Not very low \\
\hline Glycine (blood) & 500.00 & $\mu \mathrm{mol} / \mathrm{l}$ & $178-513$ & \\
\hline Glutamic acid (blood) & 27.90 & $\mu \mathrm{mol} / \mathrm{l}$ & $18.1-155.9$ & \\
\hline Leucine + Isoleucine (blood) & 78.50 & $\mu \mathrm{mol} / \mathrm{l}$ & $70-145$ & \\
\hline Lysine (blood) & 239.00 & $\mu \mathrm{mol} / \mathrm{l}$ & $94-278$ & \\
\hline Methionine (blood) & 15.00 & $\mu \mathrm{mol} / \mathrm{l}$ & $15-37$ & \\
\hline Ornithine (blood) & 39.20 & $\mu \mathrm{mol} / \mathrm{l}$ & $39-61$ & \\
\hline Proline (blood) & 284.00 & $\mu \mathrm{mol} / \mathrm{l}$ & $110-417$ & \\
\hline Serine (blood) & 111.00 & $\mu \mathrm{mol} / \mathrm{l}$ & $48.7-145.2$ & \\
\hline Tyrosine (blood) & 28.60 & $\mu \mathrm{mol} / \mathrm{l}$ & $33-146$ & Not very low \\
\hline Tryptophan (blood) & 25.00 & $\mu \mathrm{mol} / /$ & $23.5-93$ & \\
\hline Phenylalanine (blood) & 45.0 & $\mu \mathrm{mol} / \mathrm{l}$ & $45-93$ & \\
\hline Citrulline (blood) & 10.20 & $\mu \mathrm{mol} / \mathrm{l}$ & $10-43$ & \\
\hline
\end{tabular}

der consideration. At the same time, the change in the pattern on the polysomnogram is beyond doubt (07.03.2020).

\section{Single-photon emission computed tomography and positron emission computed tomography}

During SPECT (07.02.2020) and PET-CT (26.02.2020) of the brain in the patient, sufficient accumulation of RP is determined with signs of decreased cerebral blood flow in the occipital lobes of the brain (Fig. 2C).

\section{Laboratory diagnostics}

The results of laboratory tests of the patient are presented in Table 3.

\section{Neurological status at discharge}

Vegetative state. CRS-R: $1+0+1+0+$ $+0+2=4$ points. There is a diffuse increase in muscle tone (10.04.2020).

\section{Treatment}

All patients underwent multicomponent drug therapy, a complex of rehabilitation measures including exercise therapy and massage, speech therapy sessions, physiotherapy sessions with a medical psychologist (stimulation of the auditory, visual, sensory apparatus), posture treatment, and gradual verticalization of the patient. Neuromodulatory therapy courses: transcranial magnetic stimulation, except patient 3 (due to contraindications), craniocerebral hypothermia, virtual reality courses were carried out.

\section{Discussion}

Methods of instrumental diagnostics in all three patients confirm that the principal component, which determines the level of consciousness in this injury seems to be a diffuse lesion of the cerebral cortex. In all three patients, we observe diffuse slow-wave activity in the delta range, wherein the case of diffuse 
damage, indicates a total decrease in the number of nerve cells, reduction in the synapses, and the loss of integrity of associative and commissural fibres. In all patients, the absence of normal changes in sleep stages is observed. It can be explained by the low information content on the PSG in these patients due to the inability of the thin neuronal pool to translate the activity of underlying structures, such as the thalamus and basal forebrain.

Electrophysiological studies confirm the homogeneity of all three patients and also indicate a poor prognosis. Neuroimaging data in these patients do not fundamentally differ from each other and further reflects diffuse brain injury. According to functional magnetic resonance imaging, there is a dissociation of remaining uninjured networks, which significantly reduces the chances of having at least minimal signs of cognition. According to SPECT and PET-CT scan, patient 3 had the most promising prognosis in comparison with patient 1 who had 5 times higher accumulation of RP, but according to clinical examination and local assessments for the entire period of stay in the hospital, his level of consciousness did not change and remained similar to that of the other two patients in the study. When we analyse the evoked potentials in all three patients, there is difficulty in afferentation to the cerebral cortex, which may indicate the total damage of the white matter.

Prolonged immobilisation and a decrease in the level of exogenous afferentation quickly leads to axonal-demyelinating injury, which also reflects in the electroneuromyography. In all the cases, muscle tone gradually and diffusely increases over time, which is natural for the separation of cortical and underlying structures leading to a variety of contracture, which even in the case of a favourable outcome and regaining consciousness severely disable the patient. Based on aetiology, anoxic brain damage remains one of the most prognostically unfavourable causes of chronic impairment of consciousness. In contrast with traumatic brain injury in which the probability of preserving entire areas of the cerebral cortex is higher, cessation of cardiac activity or ineffective blood circulation for more than 5 minutes diffusely affects phylogenetically new parts of the brain: the frontal lobes and their connections with both the parietal and temporal parts of the cortex, which ultimately provides cognition.

Despite the multidisciplinary therapy using rhythmic transcranial magnetic stimulation, virtual reality, nootropic therapy, carried out for eight months of their hospital stay, no significant increase in the level of their consciousness were achieved; the CRS-R scores did not change from the moment of admission in all three patients.
In this article, we wanted to raise the issue of the direction of the rehabilitation vector for patients in a vegetative state. An important problem is the disturbance in circadian rhythms, probably the lack of effective sleep in patients with low levels of consciousness. The low level of the hormone melatonin, which normally peaks at night, can hardly be explained by the irregular light background at night in resuscitation or pineal gland denervation. This question, as well as the clarification of the temporal organization of the sleep-wake cycle in patients with a chronic vegetative state, remains open.

The amino acid profile and a decrease in the body mass index in the flesh up to cachexia in two patients (patient 1 with a loss of $16 \mathrm{~kg}$ during hospitalization and patient 3, who lost $29 \mathrm{~kg}$ ) speak of a metabolic disorder, the predominance of catabolism over anabolism, which is caused by the indigestibility of nutrients, their insufficiency, damage to their own flora due to massive antibiotic therapy. Insufficiency of nosocomial nutrition may be associated with incorrect calculations of the required daily calorie intake, since in most patients with anoxic brain damage, a diffuse increase in muscle tone is noted, which significantly increases the need for calories. Calculation of daily caloric intake in patients with significant muscle tone increase must necessarily rely on this kind of muscle work, which is equivalent to sports activity.

Of serious importance is the problem of preventing infectious complications in conditions of immobilization syndrome in a patient with anoxia, leading to pulmonary infections, and requiring antibiotic therapy, which, in turn, is the leading cause of the deficiency of its own intestinal flora and the development of chronic dysbiosis and, as a consequence, all the same protein-energy deficiency. We were unable to identify differences between the three patients in the level of consciousness and the prognosis relative to it, but interpreting the results of the third patient 2, who lost only $3 \mathrm{~kg}$ during hospitalization and had the most balanced amino acid composition of plasma, we can conclude that even such patients may radically differ in metabolic rate, nutrient uptake, response to standardized care, and unconscious maintenance.

\section{Conclusions}

Patients with the most unfavourable outcome in relation to the level of consciousness can maintain a satisfactory somatic state for a long time, which is critically important for maintaining vital activity, since in some cases the realization of the rehabilitation potential in patients with chronic impairment of consciousness directly depends on the preservation of 
the somatic status, an important component of which is adequate nutrition, both in terms of quantity and quality, maintenance of its own microflora, measures to create a rehabilitation environment. In some cases, especially with progressive weight loss, the amino acid profile can be used as a marker of the adequacy of nutritional support and its point correction. This is of particular importance in the light of the fact that control over the level of metabolism makes it possible to prolong the life of patients in a vegetative state of various aetiologies, thereby, in some cases, will save time for the realization of the rehabilitation potential in relation to the level of consciousness.

\section{Conflict of interests}

All authors declare that there is no conflict of interest.

\section{Funding}

None declared.

No identifiable information about the patients is included in the manuscript.

\section{References}

1. Birkun AA, Samarin SA. Ostanovka krovoobrashcheniya i serdechno-legochnaya reanimatsiya: Uchebnoye posobiye; Meditsinskaya akademiya im. S. . Georgiyevskogo, FGAOU O. Krymskiy federal'nyy universitet im. V. I. Vernadskogo, Simferopol. 2019: 54.

2. Ramiro Jl, Kumar A. Updates on management of anoxic brain injury after cardiac arrest. Mo Med. 2015; 112(2): 136-141, indexed in Pubmed: 25958659.

3. Diao MY, Zhu Y, Yang J, et al. Hypothermia protects neurons against ischemia/reperfusion-induced pyroptosis via m6A-mediated activation of PTEN and the PI3K/Akt/GSK-3 signaling pathway. Brain Res Bull. 2020; 159: 25-31, doi: 10.1016/j.brainresbull.2020.03.011, indexed in Pubmed: 32200003.
4. The Brain after Cardiac Arrest. Semin Neurol. 2017; 37(1): 19-24, doi: 10.1055/s-0036-1597833, indexed in Pubmed: 28147414.

5. Geocadin RG, Koenig MA, Jia X, et al. Management of brain injury after resuscitation from cardiac arrest. Neurol Clin. 2008; 26(2): 487-506, ix, doi: 10.1016/j.ncl.2008.03.015, indexed in Pubmed: 18514823.

6. Hoesch RE, Koenig MA, Geocadin RG. Coma after global ischemic brain injury: pathophysiology and emerging therapies. Crit Care Clin. 2008; 24(1): 25-44, vii, doi: 10.1016/j. ccc.2007.11.003, indexed in Pubmed: 18241777.

7. Welbourn C, Efstathiou N. How does the length of cardiopulmonary resuscitation affect brain damage in patients surviving cardiac arrest? A systematic review. Scand J Trauma Resusc Emerg Med. 2018; 26(1): 77, doi: 10.1186/s13049-018-0476-3, indexed in Pubmed: 30201018.

8. Sandroni C, D'Arrigo S, Nolan JP. Prognostication after cardiac arrest. Crit Care. 2018; 22(1): 150, doi: 10.1186/s13054018-2060-7, indexed in Pubmed: 29871657.

9. Di Perri C, Thibaut A, Heine L, et al. Measuring consciousness in coma and related states. World J Radiol. 2014; 6(8): 589-597, doi: 10.4329/wjr.v6.i8.589, indexed in Pubmed: 25170396.

10. Kondratyeva EA, Avdunina IA, Kondratyev AN, et al. [Vegetative State: Difficulty in Identifying Consciousness and Predicting Outcome]. Vestn Ross Akad Med Nauk. 2016; 71(4): 273-280, doi: 10.15690/vramn728, indexed in Pubmed: 29297644.

11. Wolpert E. A Manual of Standardized Terminology, Techniques and Scoring System for Sleep Stages of Human Subjects. Archives of General Psychiatry. 1969; 20(2): 246, doi: 10.1001/archpsyc.1969.01740140118016.

12. Han F, Caporale N, Dan Y. Reverberation of recent visual experience in spontaneous cortical waves. Neuron. 2008; 60(2): 321-327, doi: 10.1016/j.neuron.2008.08.026, indexed in Pubmed: 18957223.

13. Shmuel A, Leopold DA. Neuronal correlates of spontaneous fluctuations in fMRI signals in monkey visual cortex: Implications for functional connectivity at rest. Hum Brain Mapp. 2008; 29(7): 751-761, doi: 10.1002/hbm.20580, indexed in Pubmed: 18465799.

14. Zhang D, Raichle ME. Disease and the brain's dark energy. Nat Rev Neurol. 2010; 6(1): 15-28, doi: 10.1038/nrneurol.2009.198, indexed in Pubmed: 20057496. 


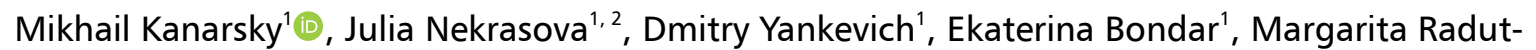
naya ${ }^{1}$, Igor Znamensky' ${ }^{1}$, Anton Kudryavtsev', Ilya Borisov' ${ }^{1}$, Pranil Pradhan', Victoria Endler', Kirill Cherkashin ${ }^{1}$, Maria Miroshnichenko ${ }^{1}$

${ }^{1}$ Federalny Instytut Naukowy finansowany z budżetu państwa — Federalne Kliniczne Centrum Badań Medycyny Intensywnej Terapii i Rehabilitacji, Moskwa, Rosja

${ }^{2}$ Federalny Państwowy Instytut Szkolnictwa Wyższego - Moskiewski Instytut Lotnictwa (Narodowy Uniwersytet Badawczy) Moskwa, Rosja

\section{Uszkodzenie mózgu z powodu niedotlenienia wywołane ogólnym niedokrwieniem: analiza trzech przypadków klinicznych}

Artykuł jest tłumaczeniem pracy: Kanarsky M., Nekrasova J., Yankevich D., Bondar E., Radutnaya M., Znamensky I., Kudryavtsev A., Borisov I., Pradhan P., Endler V., Cherkashin K., Miroshnichenko M., Anoxic brain injury due to global ischemia: analysis of three clinical cases. Palliat. Med. Pract. 2021, tom 15, nr 1: 84-92.

Należy cytować wersję pierwotną.

\section{Streszczenie}

W niniejszym artykule przedstawiono analizę trzech przypadków klinicznych pacjentów znajdujących się w permanentnym stanie wegetatywnym spowodowanym zatrzymaniem krążenia oraz długotrwałą resuscytacją krążeniowo-oddechową. Wszyscy pacjenci zostali przyjęci do Federalnego Państwowego Instytutu Szkolnictwa Wyższego — Federalnego Klinicznego Centrum Badań Medycyny Intensywnej Terapii i Rehabilitacji w Moskwie. W celu przeprowadzenia diagnostyki oraz ustalenia rokowania chorych poddano dokładnym badaniom, obejmującym elektroencefalografię, polisomnografię, pozytonową emisyjną tomografię komputerową, tomografię komputerową pojedynczych fotonów, perfuzyjną tomografię komputerową, elektroneuromiografię, badania potencjałów wywołanych, badania laboratoryjne oraz inne dostępne badania. Przedmiotowe metody diagnostyczne potwierdzają główny element składowy decydujący o poziomie świadomości przy tego typu uszkodzeniach — rozproszone uszkodzenie kory mózgowej. Realizacja potencjału rehabilitacyjnego u takich pacjentów nie jest możliwa bez kontroli wsparcia żywieniowego. Profil aminokwasowy stanowi jeden ze wskaźników oraz sposobów kontrolowania funkcji metabolicznych. Palliat Med Pract 2021; 15, 1: 93-102

Słowa kluczowe: zaburzenia świadomości, niedokrwienie ogólne, profil aminokwasowy, potencjał rehabilitacyjny, melatonina

\section{Adres do korespondencji:}

Julia Nekrasova

Federalny Instytut Naukowy finansowany z budżetu państwa — Federalne Kliniczne Centrum Badań Medycyny Intensywnej Terapii i Rehabilitacji, Moskwa, Rosja

e-mail: nekrasova84@yandex.ru 


\section{Wstęp}

Zatrzymanie krążenia oznacza ustanie aktywności elektrycznej powodujące niezdolność kurczenia się serca, co prowadzi do całkowitego zablokowania dostawy tlenu oraz glukozy do tkanek [1]. Po około 20 sekundach niedoboru tlenu następuje utrata przytomności, natomiast po 5 minutach następuje wyczerpanie zapasów glukozy i tlenu w bardzo wrażliwej na nie tkance nerwowej. Przerwa w syntezie adenozyno-5 -trifosforanu (ARP) uniemożliwia pracę ATP-zależnej pompy jonowej sodowo-potasowej, co z kolei prowadzi do dysfunkcji błony komórkowej, redystrybucji Na i wprowadzenia $\mathrm{Ca}$ do komórki [2]. Wzrost przepuszczalności błony dla Ca powoduje aktywację zależnych od kalmoduliny kinaz, lipaz i endonukleaz białkowych, co z kolei prowadzi do uszkodzenia błony i organelli komórkowych, oraz uwolnienia glutaminianu, wraz z przenikaniem Ca do wnętrza komórki, powodującym zjawisko ekscytotoksyczności. Istotną rolę zarówno w niedokrwieniu, jak i reperfuzji odgrywa wzrost w produkcji wolnych rodników, w wyniku którego następuje szereg patologicznych procesów biochemicznych. Ostatecznie prowadzi to do śmierci komórki poprzez mechanizmy martwicy, apoptozy i piroptozy [3, 4].

Neurony projekcyjne kory mózgowej, komórki Purkinjego móżdżku oraz róg Amona (CA-1, cornu ammonis) w hipokampie są obszarami szczególnie podatnymi na niedokrwienie, natomiast pień mózgu, wzgórze oraz podwzgórze są na nie bardziej odporne [5]. Pod wieloma względami to właśnie ta różnica w zakresie podatności na niedokrwienie powoduje przewlekłe upośledzenie świadomości po zatrzymaniu krążenia i późniejszej resuscytacji krążeniowo-oddechowej. Podczas gdy działanie pnia mózgu oraz struktur podwzgórza jest stosunkowo niezaburzone, dochodzi do znacznego upośledzenia włókien asocjacyjnych, komisuralnych oraz wzgórzowo-korowych, które są przyczyną stanu wegetatywnego [6].

Dzięki postępom w zakresie RKO resuscytacji krążeniowo-oddechowej zwiększyła się przeżywalność pacjentów, u których wystąpiło nagłe zatrzymanie krążenia [3]. Zatrzymanie krążenia zabija w Rosji około 250000 ludzi rocznie. W warunkach pozaszpitalnych przeżywa około $10 \%$ chorych, natomiast w klinikach i szpitalach odsetek ten zwiększa się do $22 \%$. U około jednej trzeciej chorych, którzy przeżyli zatrzymanie krążenia, występują utrzymujące się deficyty neurologiczne [1]. Uraz reperfuzyjny występuje na początku resuscytacji krążeniowo-oddechowej, powodując stres oksydacyjny, powstanie wolnych rodników oraz reaktywnych form tlenu [3]. Są one wysoce destrukcyjne i reagują z wieloma makrocząsteczkami, w tym kwasem dezoksyrybonukleinowym (DNA), a także białkami i lipidami. Poza tym, ogólna reperfuzja prowadzi do aktywacji leukocytów, indukując odpowiedź na stres zapalny, zaburzając barierę krew-mózg oraz sprzyjając dalszym uszkodzeniom na skutek wycieku płynu do przestrzeni międzykomórkowej, co powoduje obrzęk mózgu [3]. Resuscytacja krążeniowo-oddechowa częściowo odwraca niedokrwienie, jednak nie można dzięki niej skutecznie utrzymać ciśnienia perfuzyjnego mózgu, które pozostaje niskie do momentu przywrócenia naturalnego przepływu krwi, po czym następuje dalsze uszkodzenie reperfuzyjne [7].

Biorąc pod uwagę znaczne uszkodzenia powstające w wyniku przeprowadzenia resuscytacji krążeniowo-oddechowej, decyzja dotycząca chwili jej przerwania u pacjentów bez naturalnego krążenia jest niełatwa i złożona. Europejska i Amerykańska Rada Resuscytacji radzą, aby przerwać resuscytację krążeniowo-oddechową po 20 minutach asystolii, jednak w praktyce się tego nie robi. Warto zauważyć, że u niektórych osób poddawanych dłuższej resuscytacji konsekwencje neurologiczne są minimalne, co sugeruje, że każdy człowiek posiada indywidualną tolerancję na niedotlenienie, toteż przerwanie resuscytacji wyłącznie ze względu na ryzyko wystąpienia deficytów neurologicznych jest nieakceptowalne [7].

Wystąpienie stanu wegetatywnego (VS, vegetative state) z powodu ogólnego niedotlenienia jest zjawiskiem niekorzystnym prognostycznie [8]. Stan wegetatywny uznaje się za permanentny po 3 miesiącach od nietraumatycznego urazu mózgu. Permanentny stan wegetatywny oznacza, że przywrócenie świadomości jest niemożliwe $[9,10]$. W niniejszej pracy przeanalizowano trzy przypadki kliniczne pacjentów w permanentnym stanie wegetatywnym wynikającym z zatrzymania krążenia oraz długotrwałej resuscytacji krążeniowo-oddechowej, przyjętych w celu rehabilitacji do Federalnego Instytutu Naukowego - Federalnego Klinicznego Centrum Badań Medycyny Intensywnej Terapii i Rehabilitacji w Moskwie.

\section{Przypadek 1}

\section{Historia leczenia}

Dnia 4.10.2019 roku, w trakcie zabiegu przezcewnikowej implantacji zastawki aortalnej mającego na celu zwężenie ujścia tętniczego, u 75-letniego mężczyzny wystąpiło zatrzymanie krążenia. Resuscytacja trwała 33 minuty. Pacjent był w śpiączce od 04.10.2019 do 14.10.2019. Pacjent przeszedł w stan wegetatywny dnia 15.10.2019.

\section{Stan neurologiczny w chwili przyjęcia}

Stan wegetatywny. Skala wybudzenia ze śpiączki - poprawiona (CRS-R, Coma recovery scale — revi- 
sed): $1+1+1+0+0+1=4$ punktów. Odruchy pnia mózgu zachowane. Napięcie mięśniowe obniżone we wszystkich kończynach (26.11.2019).

\section{Przedmiotowe metody diagnostyczne}

Tomografia komputerowa mózgu oraz perfuzyjna CT (26.11.2019). W obrazie CT zauważalne obniżenie gęstości istoty szarej w mózgu; zmiany były bardziej wyraźne wokół komór bocznych. Podczas perfuzyjnej CT zaobserwowano zmniejszenie objętości oraz wolniejszy przepływ krwi w obszarach, w których wystąpiła leukoarajoza, wokół rogów skroniowych. Zaobserwowano również obszary, w których wszystkie parametry perfuzji były obniżone (ryc. 1A).

\section{Badanie potencjałów wywołanych mózgu}

W badaniu potencjałów wywołanych mózgu na tle utrzymania normalnego przewodnictwa z poziomu obwodowego (27.11.2019) zaobserwowano trudności w przewodzeniu na poziomie struktur wewnątrz pnia mózgu, a także spadek amplitudy odpowiedzi korowej po obu stronach, oraz wzrost czasu przewodzenia centralnego (po lewej), co również sugeruje trudności w przewodzeniu sygnałów aferentnych w korze mózgowej (ryc. 2A).

\section{Elektroneuromiografia}

Pacjenta poddano miografii stymulacyjnej nerwów długich kończyn górnych (27.11.2019). Zaobserwowano wyraźne obniżenie amplitudy reakcji motorycznej ze wszystkich nerwów wraz z obniżeniem tempa propagacji wzbudzenia wzdłuż lewego nerwu łokciowego oraz nerwu pośrodkowego. Ustalenia wskazują na zmiany demielizacyjno-aksonalne (ryc. 3A).

\section{Elektroencefalografia}

Rutynowe badanie przeprowadzono 28.11.2019 przy użyciu urządzenia Nicolet w10-20HB. Elektroencefalografia (EEG) wykazała aktywność rozproszonych fal wolnych głównie w zakresie delta o częstotliwości $0,5 \mathrm{~Hz}$ oraz amplitudzie do $60 \mathrm{mV}$. Reaktywność rytmu na bodźce zewnętrzne nie występowała (ryc. 4A).

\section{Badanie polisomnograficzne}

Badanie przeprowadzono 10.03 .2020 przy użyciu urządzenia polisomnograficznego SOMNOscreeen oraz specjalistycznego oprogramowania opracowanego w Federalnym Klinicznym Centrum Badań Medycyny Intensywnej Opieki Medycznej i Rehabilitacji do analizy cyklu snu. Zgodnie z metodą Rechtschaffena i Kalesa [11], nocna aktywność mózgu klasyfikowana jest jako pierwsza faza snu wolnofalowego (zasypianie) z rzadkim przechodzeniem do faz III-IV. Faza druga snu wolnofalowego, wrzeciona snu oraz kompleksy K nie występują. Nie zaobserwowano oznak snu paradoksalnego. Elektrookulogram wykazał szybkie ruchy gałek ocznych, których nie można jednak sklasyfikować jako sen REM (rapid eye movement sleep) ze względu na brak atonii mięśniowej w tych okresach. W zapisach polisomnograficznych nie zaobserwowano rytmicznych zmian w fazach snu. Na tej podstawie można uznać, że u pacjenta występują głębokie zaburzenia cyklu snu i budzenia się, a także brak normalnego cyklu snu (ryc. 5A).

\section{Pozytonowa tomografia emisyjna i} tomografia emisyjna pojedynczych fotonów

W tomografii emisyjnej pojedynczych fotonów (SPECT) oraz pozytonowej tomografii emisyjnej (PET-CT) z zastosowaniem 18-fluorodeksykoglukozy (18-FDG) zaobserwowano znaczne obniżenie akumulacji omawianego radiofarmaceutyku $w$ korze mózgu oraz, w mniejszym stopniu, w móżdżku, pniu mózgu oraz jądrach podstawy (26.02.2020). Zmiany te odpowiadają rozsianemu, niedotlenieniowemu uszkodzeniu mózgu. Dane z PET-CT wskazują na obniżenie akumulacji radiofarmaceutyku (18-FDG). Oceniając ilościowo średni poziom akumulacji radiofarmaceutyku, określa się symetryczną obniżoną akumulację FDG w płatach przednich, ciemieniowych, skroniowych i potylicznych - do maksymalnej wartości SUVmean $=1,5$. Ponadto, symetryczna akumulacja radiofarmaceutyku na poziomie jąder bazowych jest określana do wartości SUVmean $=1,9$. Wartość SUVmax $\mathrm{w}$ istocie szarej $=0,9$; SUVmax $\mathrm{w}$ istocie białej $=0,8$. Wskaźnik maksymalnej akumulacji w istocie szarej $\mathrm{i}$ istocie białej wynosi 1,14 ( $\mathrm{N}$ więcej niż $M=2,38 \pm 0,33)$. Obszary $w$ istocie białej, w których gęstość promieniowania rentgenowskiego jest wyraźnie obniżona, są rozproszone i odpowiadają obszarom spadku akumulacji radiofarmaceutyku. Stwierdza się zatem rozsiane uszkodzenie mózgu (ryc. 6A).

\section{Diagnostyka laboratoryjna}

Wyniki badań laboratoryjnych przeprowadzonych u pacjenta przedstawiono $w$ tabeli 1 .

\section{Stan neurologiczny podczas wizyty kontrolnej}

StanwegetatywnyCRS-R: $1+1+1+0+0+2=5$ punktów. Wzrost napięcia mięśniowego (09.04.2020).

\section{Przypadek 2}

\section{Historia leczenia}

Dnia 10.08.2019 roku 45-letniemu pacjentowi zaczął doskwierać ból w klatce piersiowej. Po 4 go- 
Tabela 1. Wyniki badań laboratoryjnych pacjenta

\begin{tabular}{|c|c|c|c|c|}
\hline Badania diagnostyczne & Wyniki & Jednostki & Prawidłowy zakres & Uwagi \\
\hline Kortyzol o 2:00 w nocy & 17 & $\mu \mathrm{g} / \mathrm{dl}$ & $2,5-12,5$ & Wysoki \\
\hline Serotonina & 348,09 & $\mathrm{ng} / \mathrm{ml}$ & $70-270$ & Bardzo wysoki \\
\hline Melatonina o 2:00 w nocy & 1,3 & $\mathrm{pg} / \mathrm{ml}$ & $\begin{array}{l}\text { Rano: } \\
\text { 15,0-30,0 } \\
\text { Popołudnie: } \\
\text { < 4,9 } \\
\text { Wieczór: (od 22:00 do 24:00) } \\
\text { 8,0-40,0 } \\
\text { Noc: } \\
52,3-149,4\end{array}$ & Bardzo niskie \\
\hline Alanina (krew) & 198,00 & $\mu \mathrm{mol} / \mathrm{l}$ & 239-345 & Niski \\
\hline Arganina (krew) & 36,00 & $\mu \mathrm{mol} / \mathrm{l}$ & $53-71$ & Niski \\
\hline Kwas asparaginowy (krew) & 4,53 & $\mu \mathrm{mol} / \mathrm{l}$ & $0,9-7,4$ & \\
\hline Walina (krew) & 74,7 & $\mu \mathrm{mol} / \mathrm{l}$ & 80-199 & Niski \\
\hline Glicyna (krew) & 409,00 & $\mu \mathrm{mol} / \mathrm{l}$ & $178-513$ & \\
\hline Kwas glutaminowy (krew) & 31,40 & $\mu \mathrm{mol} / \mathrm{l}$ & $18,1-155,9$ & \\
\hline Leucyna + Izoleucyna (krew) & 61,30 & $\mu \mathrm{mol} / \mathrm{l}$ & $70-145$ & Bardzo niskie \\
\hline Lizyna (krew) & 121,00 & $\mu \mathrm{mol} / \mathrm{l}$ & $94-278$ & \\
\hline Metionina (krew) & 18.50 & $\mu \mathrm{mol} / \mathrm{l}$ & $15-37$ & \\
\hline Ornityna (krew) & 44.60 & $\mu \mathrm{mol} / \mathrm{l}$ & $39-61$ & \\
\hline Prolina (krew) & 333,00 & $\mu \mathrm{mol} / \mathrm{l}$ & $110-417$ & \\
\hline Seryna (krew) & 62,70 & $\mu \mathrm{mol} / \mathrm{l}$ & $48,7-145,2$ & \\
\hline Tyrozyna (krew) & 78,30 & $\mu \mathrm{mol} / \mathrm{l}$ & $33-146$ & \\
\hline Tryptofan (krew) & 21,50 & $\mu \mathrm{mol} / \mathrm{l}$ & $23,5-93$ & Niski \\
\hline Fenyloalanina (krew) & 63,7 & $\mu \mathrm{mol} / \mathrm{l}$ & $45-93$ & \\
\hline Citrulina (krew) & 12,00 & $\mu \mathrm{mol} / \mathrm{l}$ & $10-43$ & \\
\hline
\end{tabular}

dzinach od pojawienia się bólu została wezwana karetka. Podczas badania wystąpiło migotanie komór i doszło do asystolii. Resuscytacja trwała 20 minut. Pacjenta przyjęto do szpitala, gdzie zdiagnozowano u niego chorobę wieńcową: ostry zawał ściany przednio-bocznej serca z uniesieniem odcinka S-T. Wykonano udrażnianie, balonowe poszerzanie naczyń oraz stentowanie przedniej tętnicy zstępującej. Dnia 21.08.2019 pacjent przeszedł ze stanu śpiączki w stan wegetatywny.

\section{Stan neurologiczny $w$ chwili przyjęcia}

StanwegetatywnyCRS-R: $1+0+2+0+0+2=5$ punktów. Reagował na bodźce bólowe minimalnym zginaniem górnych kończyn. Ruchy szczęki dolnej - szczękościsk. Odruchy pnia mózgu zachowane. Obniżone napięcie mięśniowe w kończynach dolnych, zwiększona spastyczność w kończynach górnych (wg zmodyfikowanej skali spastyczności Ashwortha — do 2) (11.10.2019).

\section{Przedmiotowe metody diagnostyczne}

CT mózgu oraz perfuzyjna CT

W CT (14.10.2019) zaobserwowano znaczne obniżenie gęstości istoty szarej wokół komór, zmiany był wyraźniejsze na poziomie rogów tylnych i skroniowych komór bocznych.Badanie wykazało również obszar obniżonej gęstości w regionie jąder podstawy po lewej stronie. Perfuzyjna CT wykazała zmniejszenie objętości oraz prędkości przepływu krwi wokół komór i płatów potylicznych, także poziomie istoty białej płatów potylicznych (ryc. 1B).

\section{Czynnościowe obrazowanie rezonansem magnetycznym}

W ramach badania dokonano mapowania sieci stanu spoczynkowego, charakteryzujących aktywność mózgu, która nie bierze udziału w wykonywaniu konkretnych zdań (w literaturze zwana również stanem spoczynku) [12-14] lub stanem spoczynku/odprężonego czuwania. Ze względu na brak możliwości nawią- 
zania kontaktu z pacjentem instrukcji nie udzielono. W trakcie badań nie wykryto sieci wzrokowej w jej klasycznej formie, ale nastąpiła aktywacja kory wzrokowej. Sieć funkcji wykonawczych, sieć istotności oraz sieć mowy, typowe dla przytomnych pacjentów, nie zostały wyodrębnione. Sieci słuchowej i sensomotorycznej również nie wyodrębniono.

Podczas analizy sieci domyślnej zaobserwowano całkowity brak tylnych (ciemieniowych i przyśrodkowych) elementów aktywacji, spadek częstotliwości oraz ogólną dezorganizację oscylacji przednich węzłów sieci w porównaniu ze stanem prawidłowym. W sieci wzrokowej w stanie spoczynku zaobserwowano u pacjenta znaczny spadek amplitudy aktywacji, a także nieregularny rytm o niskiej częstotliwości i niskiej amplitudzie w porównaniu ze stanem prawidłowym (29.10.2019) (ryc. 7A).

\section{Dwunastogodzinna obserwacja elektroencefalograficzna}

Aktywność w EEG (17.10.2019) bliska jest izolinii (amplituda sygnału nie przekracza $5 \mu \mathrm{V}$ ). Krzywa w tle zdominowana jest przez niskoamplitudową aktywność fal wolnych, głównie w zakresie delta o częstotliwości 0,5-1,5 Hz (ryc. 4B). Nie zaobserwowano zmian w aktywności EEG w tle na przestrzeni czasu.

\section{Badanie polisomnograficzne}

$\mathrm{Na}$ hipnogramie wykonanym w dniu 14.01.2020 (Rys. 5B) widoczna jest nieuporządkowana zmiana wskaźników poligraficznych. Dominująca aktywność fal wolnych w mózgu, klasyfikowana jako fazy III-IV snu wolnofalowego, zastąpiona jest obrazem polisomnograficznym odpowiadającym fazie I lub przebudzeniu, co najprawdopodobniej spowodowane jest zwiększoną aktywnością mięśni w tych okresach i występowaniem artefaktów mięśniowych w EEG.

\section{Potencjały wywołane mózgu}

Dnia 17.10.2019 pacjent został poddany badaniu somatosensorycznych potencjałów wywołanych (SSEP, somatosensory evoked potentials) poprzez obustronną stymulację nerwów środkowych. Zgodnie z badaniem SSEP, parametry reakcji z poziomu obwodowego pozostają w prawidłowym zakresie $(D>S)$. Przewodzenie jest nieco utrudnione na poziomie struktur pnia mózgu po lewej stronie (wzdłuż górnej granicy normy). Amplituda odpowiedzi korowej jest obniżona po obu stronach (bardziej po stronie lewej); czas przewodnictwa środkowego jest dłuższy. Brak odpowiedzi korowych. Uzyskane dane wskazują na trudności w zakresie aferentacji w korze mózgowej.

Dnia 27.12.2019 pacjenta poddano akustycznemu badaniu potencjałów wywołanych z pnia mó- zgu (ASEP, acoustic stem evoked potentials) oraz wzrokowych potencjałów wywołanych (VEP, visual evoked potentials) (patrz: materiały uzupełniające, ryc. 2B). Analizując wyniki analizy badania ASEP zaobserwowano trudności w przewodzeniu na poziomie struktur słuchowych wewnątrz pnia mózgu po stronie prawej: wzrost latencji I, V oraz spadek amplitudy szczytu V.

Analiza wyników VEP z lampą błyskową LED wykazała problem w przewodzeniu na poziomie skrzyżowania nerwów wzrokowych po obu stronach (spadek amplitudy P100). Amplituda odpowiedzi korowej jest obustronnie obniżona (w większym stopniu po stronie lewej). Czas przewodnictwa środkowego jest zachowany.

\section{Emisyjna CT pojedynczych fotonów oraz pozytonowa CT}

Ocena wizualna sekcji przekrojowych SPECT oraz CT (PET) mózgu pacjenta wskazuje na znaczny spadek akumulacji radiofarmaceutyku, przede wszystkim w prawej półkuli mózgu, obustronnie w płatach ciemieniowych, ze względu na znaczny spadek przepływu krwi w mózgu w wyniku uszkodzenia niedotlenieniowego (07.02.2020) (ryc. 6B).

Na podstawie oceny wizualnej danych PET-CT zauważono spadek akumulacji radiofarmaceutyku. Średni poziom akumulacji radiofarmaceutyku, symetryczną akumulację 18-FDG w płatach przednich, potylicznych, skroniowych i ciemieniowych, określono na poziomie maksymalnej wartości SUVmean $=3,2$. Ponadto, symetryczną akumulację radiofarmaceutyku na poziomie jąder bazowych określono na poziomie wartości SUVmean $=5,8$, SUVmax $\mathrm{w}$ istocie szarej $=4,7$; SUVmax $w$ istocie białej $=3,4$. W płatach potylicznych obserwuje się lokalnie obszary ze spadkiem gęstości promieniowania rentgenowskiego istoty białej przy jednoczesnym spadku akumulacji 18-FDG. Gęstość promieniowania w istocie białej mózgu jest obniżona, głównie w regionach okołokomorowych. Rozpoznaje się rozsiane uszkodzenie mózgu.

\section{Diagnostyka laboratoryjna}

Wyniki badań laboratoryjnych przeprowadzonych u pacjenta przedstawiono $\mathrm{w}$ tabeli 2 .

\section{Stan neurologiczny w momencie wypisu}

StanwegetatywnyCRS-R: $1+1+2+0+0+2=6$ punktów. Występuje obustronny wzrost napięcia mięśniowego w dolnych kończynach $w$ regionie proksymalnym i dystalnym, do 2 punktów na zmodyfikowanej skali spastyczności Ashwortha. W górnych kończynach obustronnie w części proksymalnej i dystalnej, do 3 punktów (10.04.2020). 
Tabela 2. Wyniki badań laboratoryjnych pacjenta

\begin{tabular}{|c|c|c|c|c|}
\hline Badania diagnostyczne & Wyniki & Jednostki & Prawidłowy zakres & Uwagi \\
\hline Kortyzol o 2:00 w nocy & 14 & $\mu \mathrm{g} / \mathrm{dl}$ & $2,5-12,5$ & Wysoki \\
\hline Serotonina & 175,43 & $\mathrm{ng} / \mathrm{ml}$ & $70-270$ & \\
\hline Melatonina o 2:00 w nocy & 7,2 & $\mathrm{pg} / \mathrm{ml}$ & $\begin{array}{l}\text { Rano: } \\
\text { 15,0-30,0 } \\
\text { Popołudnie: } \\
<4,9 \\
\text { Wieczór (od 22:00 do 24:00) } \\
8,0-40,0 \\
\text { Noc: } \\
52,3-149,4\end{array}$ & Niski \\
\hline Alanina (krew) & 295,00 & $\mu \mathrm{mol} / \mathrm{l}$ & 239-345 & \\
\hline Arganina (krew) & 53,00 & $\mu \mathrm{mol} / \mathrm{l}$ & $53-71$ & \\
\hline Kwas asparaginowy (krew) & 2,52 & $\mu \mathrm{mol} / \mathrm{l}$ & $0,9-7,4$ & \\
\hline Walina (krew) & 89,5 & $\mu \mathrm{mol} / \mathrm{l}$ & 80-199 & \\
\hline Glicyna (krew) & 218,00 & $\mu \mathrm{mol} / \mathrm{l}$ & $178-513$ & \\
\hline Kwas glutaminowy (krew) & 30,10 & $\mu \mathrm{mol} / \mathrm{l}$ & $18,1-155,9$ & \\
\hline Leucyna + Izoleucyna (krew) & 71,60 & $\mu \mathrm{mol} / \mathrm{l}$ & $70-145$ & \\
\hline Lizyna (krew) & 75,50 & $\mu \mathrm{mol} / \mathrm{l}$ & $94-278$ & Niski \\
\hline Metionina (krew) & 16,00 & $\mu \mathrm{mol} / \mathrm{l}$ & $15-37$ & \\
\hline Ornityna (krew) & 53,50 & $\mu \mathrm{mol} / \mathrm{l}$ & $39-61$ & \\
\hline Prolina (krew) & 292,00 & $\mu \mathrm{mol} / \mathrm{l}$ & $110-417$ & \\
\hline Seryna (krew) & 84,20 & $\mu \mathrm{mol} / \mathrm{l}$ & $48,7-145,2$ & \\
\hline Tyrozyna (krew) & 86,00 & $\mu \mathrm{mol} / \mathrm{l}$ & $33-146$ & \\
\hline Tryptofan (krew) & 80,40 & $\mu \mathrm{mol} / \mathrm{l}$ & $23,5-93$ & \\
\hline Fenyloalanina (krew) & 66,7 & $\mu \mathrm{mol} / \mathrm{l}$ & $45-93$ & \\
\hline Citrulina (krew) & 17,20 & $\mu \mathrm{mol} / \mathrm{l}$ & $10-43$ & \\
\hline
\end{tabular}

\section{Przypadek 3}

\section{Historia leczenia}

$Z$ dokumentacji medycznej wynika, że 36-letni pacjent został przetransportowany do szpitala z miejsca wypadku (motocyklista) dnia 6.09.2019 roku. Dnia 12.09.2019, podczas operacji usunięcia śledziony, nastąpiło zatrzymanie akcji serca. Nie jest znany czas wykonywania resuscytacji krążeniowo-oddechowej. W dniu 20.09.2019 pacjent przeszedł ze stanu śpiączki w stan wegetatywny.

\section{Stan neurologiczny w chwili przyjęcia}

StanwegetatywnyCRS-R: $1+0+1+0+0+2=4$ punktów. Reakcja na bodziec bólowy: minimalne zgięcie ramienia. Odruchy pnia mózgu zachowane. Obniżone napięcie mięśniowe w kończynach. Zwiększenie napięcia mięśniowego mięśni ustno-żuchwowych (25.10.2019).

\section{Przedmiotowe metody diagnostyczne}

Badanie CT mózgu oraz perfuzyjna CT

Badanie CT wykazało symetryczne obszary obniżonej gęstości w płatach czołowych i potylicznych. Podczas perfuzyjnej CT zauważono znaczny spadek prędkości przepływu krwi oraz objętości krwi w płatach potylicznych i czołowych (ryc. 1C).

\section{Elektroneuromiografia}

Pacjenta poddano miografii stymulacyjnej nerwów długich kończyn górnych. Amplituda reakcji motorycznej zarówno nerwów pośrodkowych, jak i łokciowych była obniżona we wszystkich punktach poddanych stymulacji. Prędkość propagacji pobudzenia wzdłuż wszystkich badanych nerwów mieściła się w prawidłowym zakresie. Uzyskane dane są charakterystyczne dla zmian na poziomie aksonalnym (19.11.2019) (ryc. 1B). 


\section{Potencjały wywołane}

Multimodalne badanie potencjałów wywołanych - badania SSEP, ASEP) oraz VEP wykonano dnia 04.02.2020 oraz 05.02.2020. Badanie SSEP wykazało oznaki zachowania parametrów odpowiedzi na poziomie obwodowym, choć stwierdzono, że występują w ich zakresie trudności w przewodzeniu na poziomie struktur wewnętrznych pnia mózgu (wzrost latencji szczytu N13). Stwierdzono również obustronny spadek amplitudy odpowiedzi korowej ( $w$ większym stopniu po lewej stronie) $z$ wydłużeniem czasu przewodzenia środkowego (po lewej), co wskazuje na trudności w zakresie aferencji w korze mózgowej. Badanie ASEP wykazało spowolnienie przewodzenia w dystalnej części nerwu słuchowego po prawej (szczyt I), w dolnych guzkach poczwórnego (szczyt V). Analiza badania VEP z błyskiem diody elektroluminescencyjnej (LED) pokazuje trudności w przewodzeniu na poziomie struktur słuchowych wewnątrz pnia mózgu (spadek amplitudy szczytu P100) po obu stronach, przy utrzymaniu prawidłowego przewodzenia na poziomie skrzyżowania włókien nerwu wzrokowego (ryc. 2C).

\section{Elektroencefalografia}

W EEG z dnia 01.11.2019 widoczna jest powolna aktywność elektryczna, zdominowana przez fale $z$ zakresu delta (ryc. 4C). Nie wystąpiły istotne zmiany $w$ zakresie dynamiki pomiędzy EEG z 04.02.2020 a 11.03.2020.

\section{Badanie polisomnograficzne}

Hipnogram (ryc. 5C) ukazuje zmianę z pośredniej szybkiej amplitudy fal niskich na aktywność wolnofalową odpowiadającą fazom snu II-IV u osoby zdrowej. Opisana powyżej zmiana cyklu snu nie jest cykliczna; obecność pośredniej aktywności fal szybkich na początku okresu snu można wyjaśnić obecnością artefaktów mięśniowych w EEG. Wyciągnięcie jednoznacznych wniosków w kwestii występowania lub niewystępowania snu w omawianym okresie jest zatem niemożliwe. Jednocześnie, zmiana w cyklu odnotowana na polisomnogramie jest niewątpliwa (07.03.2020).

\section{Emisyjna CT pojedynczych fotonów oraz pozytonowa CT}

Podczas badania SPECT $(07.02 .2020)$ i CT (PET) (26.02.2020) zaobserwowano u pacjenta dostateczną akumulację radiofarmaceutyku i oznaki zmniejszonego przepływu krwi w płatach potylicznych (ryc. 2C).

\section{Diagnostyka laboratoryjna}

Wyniki badań laboratoryjnych przeprowadzonych u pacjenta przedstawiono $\mathrm{w}$ tabeli 3 .

\section{Stan neurologiczny w chwili wypisu}

StanwegetatywnyCRS-R: $1+0+1+0+0+2=4$ punktów. Rozproszony wzrost napięcia mięśniowego (10.04.2020).

\section{Leczenie}

Wszyscy pacjenci zostali poddani wieloskładnikowemu leczeniu farmakologicznemu, kompleksowej rehabilitacji obejmującej terapię ruchową i masaże, sesje logopedyczne, fizjoterapeutyczne prowadzone przez psychologa medycznego (stymulacja aparatu słuchowego, wzrokowego i aparatu czucia), leczenie postawy oraz stopniową wertykalizację pacjenta. Terapia neuromodulacyjna: przezczaszkowa stymulacja magnetyczna, poza pacjentem 3 (ze względu na przeciwwskazania), hipotermia czaszkowo-mózgowa, sesje rzeczywistości wirtualnej.

\section{Dyskusja}

Metody diagnostyki przedmiotowej zastosowane u wszystkich trzech pacjentów potwierdzają, że głównym elementem decydującym o stopniu świadomości przy omawianym urazie są rozsiane zmiany w korze mózgowej. U wszystkich trzech pacjentów zaobserwowano rozproszoną aktywność fal wolnych w zakresie delta, natomiast przypadek urazu rozsianego wskazuje na całkowity spadek liczby komórek nerwowych, redukcję synaps oraz utratę integralności komórek asocjacyjnych i komisuralnych. U wszystkich pacjentów zaobserwowano brak prawidłowych zmian w fazach snu. Można to wytłumaczyć niską zawartością informacji w PSG wynikającą z niezdolności wąskiej puli neuronów do translacji aktywności podstawowych struktur, takich jak wzgórze czy podstawa podomózgowia.

Badania elektrofizjologiczne potwierdzają jednakowość wszystkich trzech pacjentów oraz wskazują, że rokowanie jest złe. Dane $z$ neuroobrazowania wykonanego u pacjentów nie różnią się w sposób zasadniczy i dodatkowo odzwierciedlają rozsiane urazy mózgu. Według funkcjonalnego obrazowania metodą rezonansu magnetycznego, u pacjentów zachodzi dysocjacja pozostałych, nieuszkodzonych sieci, co znacząco obniża szanse na uzyskanie choćby minimalnych oznak zdolności poznawczych. Według wyników SPECT i CT (PET), rokowanie było najbardziej obiecujące u pacjenta 3 w porównaniu z pacjentem 1 , u którego akumulacja radiofarmaceutyku była 5 razy wyższa, lecz według badań klinicznych oraz ocen dokonanych w szpitalu w całym okresie jego pobytu w placówce, u pacjenta nie zaszły zmiany w zakresie poziomu świadomości, a jego stan był podobny do stanu pozostałych dwóch pacjentów objętych bada- 
Tabela 3. Wyniki badań laboratoryjnych pacjenta

\begin{tabular}{|c|c|c|c|c|}
\hline Badania diagnostyczne & Wyniki & Jednostki & Prawidłowy zakres & Uwagi \\
\hline Kortyzol o 2:00 w nocy & 13,5 & $\mu \mathrm{g} / \mathrm{dl}$ & $2,5-12,5$ & Wysoki \\
\hline Serotonina & 301,67 & $\mathrm{ng} / \mathrm{ml}$ & $70-270$ & Bardzo wysoki \\
\hline Melatonina o 2:00 w nocy. & 37,2 & $\mathrm{pg} / \mathrm{ml}$ & $\begin{array}{l}\text { Rano: } \\
\text { 15,0-30,0 } \\
\text { Popołudnie: } \\
<4,9 \\
\text { Wieczór (od 22:00 do 24:00) } \\
8,0-40,0 \\
\text { Noc: } \\
52,3-149,4\end{array}$ & \\
\hline Alanina (krew) & 167,00 & $\mu \mathrm{mol} / \mathrm{l}$ & 239-345 & Niski \\
\hline Arganina (krew) & 34,20 & $\mu \mathrm{mol} / \mathrm{l}$ & $53-71$ & Niski \\
\hline Kwas asparaginowy (krew) & 2,75 & $\mu \mathrm{mol} / \mathrm{l}$ & $0,9-7,4$ & \\
\hline Walina (krew) & 75,0 & $\mu \mathrm{mol} / \mathrm{l}$ & 80-199 & Niezbyt niski \\
\hline Glicyna (krew) & 500,00 & $\mu \mathrm{mol} / \mathrm{l}$ & $178-513$ & \\
\hline Kwas glutaminowy (krew) & 27,90 & $\mu \mathrm{mol} / \mathrm{l}$ & $18,1-155,9$ & \\
\hline Leucyna + Izoleucyna (krew) & 78,50 & $\mu \mathrm{mol} / \mathrm{l}$ & $70-145$ & \\
\hline Lizyna (krew) & 239,00 & $\mu \mathrm{mol} / \mathrm{l}$ & $94-278$ & \\
\hline Metionina (krew) & 15,00 & $\mu \mathrm{mol} / \mathrm{l}$ & $15-37$ & \\
\hline Ornityna (krew) & 39,20 & $\mu \mathrm{mol} / \mathrm{l}$ & $39-61$ & \\
\hline Prolina (krew) & 284,00 & $\mu \mathrm{mol} / \mathrm{l}$ & $110-417$ & \\
\hline Seryna (krew) & 111,00 & $\mu \mathrm{mol} / \mathrm{l}$ & $48,7-145,2$ & \\
\hline Tyrozyna (krew) & 28,60 & $\mu \mathrm{mol} / \mathrm{l}$ & $33-146$ & Niezbyt niski \\
\hline Tryptofan (krew) & 25,00 & $\mu \mathrm{mol} / \mathrm{l}$ & $23,5-93$ & \\
\hline Fenyloalanina (krew) & 45,0 & $\mu \mathrm{mol} / \mathrm{l}$ & $45-93$ & \\
\hline Citrulina (krew) & 10,20 & $\mu \mathrm{mol} / \mathrm{l}$ & $10-43$ & \\
\hline
\end{tabular}

niem. Analizując potencjał wywołany u wszystkich trzech pacjentów możemy zaobserwować trudności w zakresie aferentacji do kory mózgowej, co wskazywać może na całkowite uszkodzenie istoty białej.

Przedłużające się unieruchomienie i spadek poziomu aferentacji egzogennej szybko prowadzą do urazów demielinizacyjno-aksonalnych, które również można zaobserwować w badaniu elektroneuromiograficznym. U wszystkich pacjentów napięcie mięśniowe zwiększało się stopniowo i w rozproszony sposób w czasie. Jest to naturalne przy oddzieleniu struktur korowych oraz struktur leżących u ich podstaw, prowadzącym do różnego rodzaju przykurczów, co nawet w przypadku korzystnych wyników leczenia i odzyskania przytomności powoduje znaczną niepełnosprawność u pacjenta. Z uwagi na etiologię, niedotlenieniowe uszkodzenie mózgu jest jedną z najgorzej rokujących przyczyn przewlekłego upośledzenia świadomości. W przeciwieństwie do traumatycznego urazu mózgu, w przypadku którego prawdopodobieństwo zachowania całych obszarów kory mózgowej jest wyższe, zatrzymanie akcji serca lub nieefektywne krążenie krwi przez czas dłuższy niż 5 minut w sposób rozproszony wpływa na filogenetycznie nowe części mózgu: płaty czołowe i ich połączenia oraz zarówno ciemieniowe, jak i skroniowe części kory mózgowej, finalnie odpowiedzialnej za zdolności poznawcze.

Pomimo wielospecjalistycznego leczenia z wykorzystaniem przezczaszkowej stymulacji magnetycznej, rzeczywistości wirtualnej, terapii nootropowej, trwającego przez okres ośmiu miesięcy pobytu pacjentów w szpitalu, nie uzyskano u nich znaczącego zwiększenia poziomu świadomości. Wyniki w skali CRS-R (skala wychodzenia ze śpiączki) nie zmieniły się u żadnego pacjenta od momentu przyjęcia do szpitala.

W niniejszym artykule autorzy chcieli omówić kwestię kierunku, w jakim prowadzi się rehabilitację pacjentów w stanie wegetatywnym. Istotnym problemem są zaburzenia rytmu całodobowego oraz prawdopodobny brak skutecznego snu u pacjentów z niskim poziomem świadomości. Niski poziom melatoniny, której szczyt stężenia występuje w nocy, trudno jest wytłumaczyć nieregularnym światłem w nocy lub odnerwieniem szyszynki. Zarówno ta kwestia, 
jak i problem organizacji cyklu snu i budzenia się u pacjentów w przewlekłym stanie wegetatywnym pozostają otwarte.

Profil aminokwasowy oraz spadek wskaźnika masy ciała aż do stanu wyniszczenia, który zaobserwowano u dwóch pacjentów (pacjent 1 stracił 16 kg podczas hospitalizacji, natomiast u pacjenta 3. spadek ten wyniósł $29 \mathrm{~kg}$ ), świadczą o występowaniu zaburzeń metabolicznych, a także przewagi katabolizmu nad anabolizmem, w wyniku nietrawienia składników odżywczych i ich niedostatku, oraz o stratach we florze bakteryjnej pacjentów spowodowanych leczeniem dużymi ilościami antybiotyków. Niewystarczalność żywienia szpitalnego może wynikać z nieprawidłowego obliczania dziennego zapotrzebowania kalorycznego, ponieważ u większości pacjentów z niedotlenieniowym uszkodzeniem mózgu obserwuje się rozproszone zwiększenie napięcia mięśniowego, co znacznie zwiększa ich zapotrzebowanie na energię. Dzienna podaż kalorii u pacjentów ze znacznym zwiększeniem napięcia mięśniowego musi być obliczana na podstawie tego rodzaju pracy mięśni, która jest równoważna z aktywnością sportową.

Ważną kwestią jest zapobieganie powikłaniom zakaźnym u pacjentów z niedotlenieniem cierpiących na zespół unieruchomienia, prowadzącym do infekcji płuc i wymagającym leczenia z zastosowaniem antybiotykoterapii, która z kolei jest główną przyczyną strat we florze bakteryjnej jelit i rozwoju przewlekłej dysbiozy oraz, w rezultacie, niedoborów energetycznych i niedoborów białka. Nie byliśmy w stanie zidentyfikować różnic pomiędzy trzema pacjentami w zakresie poziomu świadomości oraz związanego z nim rokowania, jednak na podstawie analizy wyników pacjenta 2., który stracił zaledwie 3 kg podczas hospitalizacji i u którego aminokwasowy skład osocza był najbardziej zbilansowany, można stwierdzić, że nawet u takich pacjentów znacząco mogą występować znaczące różnice $w$ zakresie szybkości metabolizmu, pobierania składników odżywczych oraz odpowiedzi na opiekę i nieświadomych procesów podtrzymywania organizmu przy życiu.

\section{Wnioski}

Pacjenci z najbardziej niekorzystnymi wynikami w zakresie poziomu świadomości mogą utrzymywać satysfakcjonujący stan somatyczny przez długi czas, co jest kluczowe dla utrzymania aktywności życiowej, ponieważ w niektórych przypadkach realizacja potencjału rehabilitacyjnego u pacjentów z przewlekłym upośledzeniem świadomości zależy bezpośrednio od ich stanu somatycznego, którego ważnym elementami składowymi są odpowiednie żywienie, zarówno w zakresie jakościowym, jak i ilościowym, zachowanie własnej flory bakteryjnej pacjenta oraz sposoby na stworzenie środowiska do rehabilitacji. W niektórych przypadkach, szczególnie przy postępującej utracie masy ciała, profil aminokwasowy może być stosowany jako wskaźnik mierzący adekwatność wsparcia żywieniowego oraz jego korekty. Jest to szczególnie ważne $z$ uwagi na fakt, że kontrolowanie metabolizmu umożliwia wydłużenie życia pacjentów z różnych przyczyn znajdujących się w stanie wegetatywnym. W niektórych przypadkach pozwala to zaoszczędzić czas potrzebny na realizację potencjału rehabilitacyjnego w odniesieniu do poziomu świadomości.

\section{Konflikt interesów}

Wszyscy autorzy oświadczają, że nie występuje konflikt interesów.

\section{Finansowanie}

Badanie nie było finansowane.

Manuskrypt nie zawiera informacji, które mogłyby umożliwić identyfikację pacjentów.

\section{Piśmiennictwo}

1. Birkun AA, Samarin SA. Ostanovka krovoobrashcheniya i serdechno-legochnaya reanimatsiya: Uchebnoye posobiye; Meditsinskaya akademiya im. S. . Georgiyevskogo, FGAOU. Krymskiy federal'nyy universitet im. V. I. Vernadskogo, Simferopol. 2019: 54.

2. Ramiro JI, Kumar A. Updates on management of anoxic brain injury after cardiac arrest. Mo Med. 2015; 112(2): 136-141, indexed in Pubmed: 25958659.

3. Diao MY, Zhu Y, Yang J, et al. Hypothermia protects neurons against $\mathrm{O}$ ischemia/reperfusion-induced pyroptosis via $\mathrm{m} 6 \mathrm{~A}$ mediated activation of PTEN and the PI3K/Akt/GSK-3 signaling pathway. Brain Res Bull. 2020; 159: 25-31, doi: 10.1016/j. brainresbull.2020.03.011, indexed in Pubmed: 32200003.

4. The Brain after Cardiac Arrest. Semin Neurol. 2017; 37(1): 19-24, doi: 10.1055/s-0036-1597833, indexed in Pubmed: 28147414.

5. Geocadin RG, Koenig MA, Jia X, et al. Management of brain injury after resuscitation from cardiac arrest. Neurol Clin. 2008; 26(2): 487-506, ix, doi: 10.1016/j.ncl.2008.03.015, indexed in Pubmed: 18514823.

6. Hoesch RE, Koenig MA, Geocadin RG. Coma after global ischemic brain injury: pathophysiology and emerging therapies. Crit Care Clin. 2008; 24(1): 25-44, vii, doi: 10.1016/j. ccc.2007.11.003, indexed in Pubmed: 18241777.

7. Welbourn C, Efstathiou N. How does the length of cardiopulmonary resuscitation affect brain damage in patients surviving cardiac arrest? A systematic review. Scand J Trauma Resusc Emerg Med. 2018; 26(1): 77, doi: 10.1186/s13049018-0476-3, indexed in Pubmed: 30201018.

8. Sandroni C, D'Arrigo S, Nolan JP. Prognostication after cardiac arrest. Crit Care. 2018; 22(1): 150, doi: 10.1186/s13054018-2060-7, indexed in Pubmed: 29871657.

9. Di Perri $C$, Thibaut A, Heine $L$, et al. Measuring consciousness in coma and related states. World J Radiol. 2014; 6(8): 589-597, doi: 10.4329/wjr.v6.i8.589, indexed in Pubmed: 25170396. 
10. Kondratyeva EA, Avdunina IA, Kondratyev AN, et al. [Vegetative State: Difficulty in Identifying Consciousness and Predicting Outcome]. Vestn Ross Akad Med Nauk. 2016; 71(4): 273-280, doi: 10.15690/vramn728, indexed in Pubmed: 29297644.

11. Wolpert E. A Manual of Standardized Terminology, Techniques and Scoring System for Sleep Stages of Human Subjects. Archives of General Psychiatry. 1969; 20(2): 246, doi: 10.1001/archpsyc. 1969.01740140118016.

12. Han F, Caporale N, Dan Y. Reverberation of recent visual experience in spontaneous cortical waves. Neuron. 2008;
60(2): 321-327, doi: 10.1016/j.neuron.2008.08.026, indexed in Pubmed: 18957223.

13. Shmuel A, Leopold DA. Neuronal correlates of spontaneous fluctuations in fMRI signals in monkey visual cortex: Implications for functional connectivity at rest. Hum Brain Mapp. 2008; 29(7): 751-761, doi: 10.1002/hbm.20580, indexed in Pubmed: 18465799.

14. Zhang D, Raichle ME. Disease and the brain's dark energy. Nat Rev Neurol. 2010; 6(1): 15-28, doi: 10.1038/nrneurol.2009.198, indexed in Pubmed: 20057496. 